\title{
Mineral and proximate composition of selected forages fed to West African dwarf
} bucks in Obio Akpa

${ }^{1}$ Eyoh, G. D., ${ }^{2}$ Ayuk, A. A., ${ }^{2}$ Anya, M. I. and ${ }^{1}$ Udo, M. D. I. Department of Animal Science, Akwa Ibom State University, Akwa Ibom State

${ }^{2}$ Department of Animal Science, University of Calabar.

\author{
Abstract \\ Corresponding author: gloryeyoh5@gmail.com:Phone : 07035232506
}

\begin{abstract}
The nutritive value of leaves from six forages was carried out. The forages were Andropogon tectorum, Panicum maximum, Aspilia aafricana, Gmelina aborea, Alchornea cordifolia and Bambusa vulgaris, and were collected from Obio-Akpa in Akwa Ibom State. The forages were analysed for proximate composition, mineral/vitamin concentrations and anti-nutritive components. Results showed no significant $(p>0.05)$ differences in the dry matter content which ranged from 86.52 to $98.36 \%$. A. africana and $G$. arborea recorded protein contents which was higher than the crude protein $(C P)$ of other forages analysed. A range of 1.94 to $5.24 \%$ and 1.28 to $5.84 \%$ were recorded for ether extract (EE) and crude fibre (CF) values for the six forages. The values reported for minerals showed that B. vulgaris had the lowest value of calcium $(0.45 \%)$ while A. tectorum was low in magnesium $(\mathrm{Mg})$ and potassium $(0.57$ and $0.22 \%)$. Highest content of vitamin $A$ and $B_{12}$ was recorded in A. tectorum (1.17 and $2.11 \mu \mathrm{g} / 100 \mathrm{~g})$, respectively. The values reported for anti-nutritive factors ranged from 0.98 to 2.23 for tannins, 1.94 to 3.76 for Saponins, 0.01 to 1.23 for oxalates, 0.22 to 0.71 for hydrogen cyanide (HCN) and 1.05 to $1.55 \mathrm{mg} / \mathrm{g}$ for phytates. The results showed that the forages studied have good nutrient contents and safe levels of anti-nutritional factors, thus they may be used as feed resources to enhance the production of ruminants.
\end{abstract}

Keywords: Forages, anti-nutritional factors, WAD bucks, minerals

\section{Introduction}

Ruminants depend on essential mineral elements from pastures for their health and performance. Minerals are the most variable amongst all the nutritional contents supplied by pastures. Underwood and Scuttle (1999) reported that pastures often fail to supply all the mineral elements needed by grazing animals in adequate quantity. Animals depend on forages to satisfy all of their requirements nutritionally under pasture system, but unfortunately forages do not supply all these needed minerals throughout the year. Mineral inadequacies in forages have been reported (Vegas and McDowell, 1997) which cause low production rates and reproductive failures. This is likely to affect the production rates of grazing animals (Judson and McFarlane, 1998). Livestock improvement demands the efficient use of available forages and other feed resources and their potentials in meeting the animal needs and maintaining their health status. Phytochemicals otherwise called antinutritional factors can be defined as toxic substances in diets of humans and animals which negatively influence their health by disturbing normal physiological functions. The significant characteristics of antinutrients can be predicted by the animal's performance, behavioural pattern and adaptation to feed. D'Mello (2000) noted that the major damages of anti-nutrients include negative impact on growth and reproduction, reduced immune-competence which leads to morbidity and mortality. These chemicals can limit the digestibility of essential nutrients by impairing normal metabolism, causing various disorders, decrease palatability and reduced growth 


\section{Mineral and proximate composition of selected forages}

rate (Soetan, 2008). However, some ruminants have ability to adapt and neutralize the possible damages (Habtamu and Negussie, 2014).

Therefore, this study was designed to investigate the mineral status and proximate composition of selected forages used by grazing animals.

\section{Materials and methods}

The leaves of six indigenous forages commonly consumed by ruminant animals were used in this study. The species were $A$. tectorum, $P$. maximum, A.africana, $G$. aborea, A. cordofolia and B. vulgaris. All the plants were harvested from Obio-Akpa in OrukAnam Local Government Area (LGA) of Akwalbom State, Nigeria. The area is located between latitude $5^{\circ} 17^{1} \mathrm{~N}$ and $5^{\circ} 27^{\circ} \mathrm{N}$ between longitude $7^{\circ} 27^{1} \mathrm{~N}$ and $7^{\circ}$ $58^{1} \mathrm{E}$ with an annual rainfall ranging from $3500 \mathrm{~mm}-5000 \mathrm{~mm}$ and average monthly temperature of $25^{\circ} \mathrm{C}$. The study location lies between latitude $4^{\circ} 28^{1} \mathrm{~N}$ and $5^{\circ} 3^{1} \mathrm{~N}$ and between longitude $7^{\circ} 27^{1} \mathrm{E}$ and $8^{\circ} 20^{1} \mathrm{E}$ with a relative humidity between $60-90 \%$ (SLUS-AK,1989). The forage samples were analysed for dry matter (DM), crude protein $(\mathrm{CP})$, ether extract (EE), crude fibre (CF) and ash according to the procedures of AOAC (2002). The mineral composition (calcium and magnesium) of the forages were analysed using atomic absorption spectrophotometry. The hydrogen cyanide (HCN) was determined by the Knowels and Watkins distillation method.), phytates was estimated as phytic acid by Maga method (1982). Tannin and Saponins were determined according to (Polshettiwaret al., 2007). Potassium and sodium was determined by flame photometry (Junsomboon and Jakmunce, 2011).

The means and standard error of means were calculated. Means were separated using Duncan's Multiple Range Test
(Duncan, 1955).

\section{Results and discussion}

The proximate composition of the leaves from Andropogon tectorum, Panicum maximum, Aspilia africana, Gmelina arborea, Alchornea cordifolia and Bambusa vulgaris is presented in Table 1. Values obtained from proximate analysis showed significant $(\mathrm{p}<0.05)$ differences among the treatment groups. However, these values did not show any consistent trend in the study. The crude protein of Gmelina arborea (GA) and Aspilia africana (AA) were higher than those of the other forages. The crude protein of the forages ranged from 2.75 to $13.24 \%$ which will provide ammonia required for rumen microorganisms to support optimum microbial activity. The use of different types of forages in small quantities can supplement poor quality pastures and crop residues (Norton, 2003). Le Houerou (1980) had a mean of $12.5 \%$ in West African browse specie with $17 \%$ for leguminous species. However, the variations in the different species can be explained by inherent characteristics of each species from soil and fix atmosphere nitrogen as in legumes (Rittner and Reed, 1992). Other factors causing variation in the chemical composition of forages include soil type and location, age of the plant used for consumption by the animals.

Highest value (5.84\%) of crude fibre was recorded in Bambusa vulgaris while the other species had moderate contents. This is in line with the reports of Njidda et al $\left(2010_{a}\right)$ that voluntary dry matter intake and digestibility are dependent on the fibre content of the forage. Fibre is known to promote softer stools with increased frequency and regularity of elimination. (Amata and Lebari, 2011). Among all the forages used in the experiment, $B$. vulgaris 


\section{Eyoh, Ayuk, Anya and Udo}

recorded the highest percentage of crude fibre $(41.85 \%)$ while the least $(12.80 \%)$ was recorded in A. africana. This may have been due to the dry season in which the experiment was conducted. Fibre is important in the diet of farm animals, it acts as diluents. Its absence in diets leads to incidence of a wide range of diseases which include colon biventricular, obesity and diabetis mellitus (Oke et al. 2007). Fibre is also necessary for proper bowel movement (Odoemelam and Ahamefule, 2006). Ash content of the forages followed the same trend as crude fibre.

The ash content which is an indication of the presence of minerals is within the ranges reported by Amata and Lebari (2011), and Kubmarawa et al (2008). The highest values (16.38\%) in Andropogon tectorum may also have been due to the high concentration of minerals. The proximate values so obtained, were contrary to those reported by Ikhimoya et al. (2007), Obua et al. (2012) and Philip and Owen (2014).

Table 1: Proximate composition of selected fodder crops used for the experiment

\begin{tabular}{|c|c|c|c|c|c|c|c|}
\hline Parameter & $\begin{array}{c}\text { Andropogon } \\
\text { tectorum } \\
\mathrm{T}_{1}\end{array}$ & $\begin{array}{l}\text { Panicum } \\
\text { Maximum } \\
\mathrm{T}_{2}\end{array}$ & $\begin{array}{l}\text { Aspilia } \\
\text { Africana } \\
\mathrm{T}_{3}\end{array}$ & $\begin{array}{l}\text { Gmelina } \\
\text { Arborea } \\
\mathrm{T}_{4}\end{array}$ & $\begin{array}{l}\text { Alchornea } \\
\text { Cordifolia } \\
\mathrm{T}_{5}\end{array}$ & $\begin{array}{l}\text { Bambusa } \\
\text { Vulgaris } \\
\mathrm{T}_{6}\end{array}$ & SEM \\
\hline DM $(\%)$ & 86.52 & 98.23 & 98.36 & 96.75 & 97.54 & 96.86 & 10.17 \\
\hline Crude protein $(\%)$ & $2.75^{\mathrm{c}}$ & $2.42^{\mathrm{c}}$ & $12.51^{\mathrm{a}}$ & $13.24^{\mathrm{a}}$ & $7.95^{\mathrm{b}}$ & $8.29^{b}$ & 2.80 \\
\hline Ether extract (\%) & $5.24^{\mathrm{a}}$ & $2.86^{\mathrm{b}}$ & $1.94^{\mathrm{c}}$ & $2.12^{\mathrm{c}}$ & $3.45^{\mathrm{b}}$ & $2.02^{\mathrm{c}}$ & 0.52 \\
\hline Crude Fibre (\%) & $3.93^{b}$ & $2.17^{\mathrm{c}}$ & $1.28^{\mathrm{c}}$ & $1.46^{\mathrm{c}}$ & $1.75^{\mathrm{c}}$ & $5.84^{\mathrm{a}}$ & 4.86 \\
\hline Ash Content ( $\%)$ & $16.38^{\mathrm{a}}$ & $2.89^{\mathrm{b}}$ & $1.79^{c}$ & $2.32^{\mathrm{b}}$ & $2.25^{\mathrm{b}}$ & $2.35^{\mathrm{b}}$ & 0.48 \\
\hline Energy (Kcal/kg) & 1735.20 & 802.60 & 1826.20 & 1778.60 & 1116.10 & 1045.00 & 182.47 \\
\hline
\end{tabular}

Results of the phytochemical analysis of six selected forages are shown in Table 2. There were no significant $(\mathrm{p}>0.05)$ differences observed among the different parameters studied except for saponin. The tannin levels reported in this study, though not significantly $(\mathrm{p}>0.05)$ different ranged from $0.98 \mathrm{mg} / \mathrm{g}$ to $2.23 \mathrm{mg} / \mathrm{g} \mathrm{DM}$ which is lower than 60 to $100 \mathrm{~g}$ DM considered to be detrimental to animals (Barry and Duncan, 1984). Similarly, Waghorn (2008) further reported that dietary condensed tannins of 2 to $3 \%$ have been shown to have beneficial effects since they reduce protein degradation in the rumen by the formation of protein tannin complex. The saponin content of the forages ranged from 1.94 $\mathrm{mg} / \mathrm{g}$ DM in Adropogon tectorum to 3.76 $\mathrm{mg} / \mathrm{g}$ DM in Gmelina arborea. Feedstuff containing saponin had been shown to be defaunating agents (Teferedegne, 2000) and capable of reducing methane production (Babayemi et al., 1999). Saponin is also found to have effect on reduction of blood and liver cholesterol, depression of growth rate, bloat in ruminant, absorption (Cheeke and Shull, 1985). The oxalate contents of the forages investigated were equally low. The oxalate ranged from $0.17-1.45 \mathrm{~g} / \mathrm{kg}$ which is likely not harmful to the animals. Akinsoyinu and Onwuka (1988) noted that oxalate has been shown to deplete calcium reserves. Reasonable amounts of calcium and phosphorous intakes will be lost via faeces and urine to the soil. Calcium oxalate adversely affects the absorption and utilization of calcium in the animal's body (Smith et al, 2013).

The hydrogen cyanide contents ranged 


\section{Mineral and proximate composition of selected forages}

from $0.22-0.71 \mathrm{mg} / \mathrm{g}$ DM. this range is negligible to pose problems to the animals. This level obtained in the study is in agreement with the observations of Kumar, (2003) that the quantity of HCN produced by most forages is too low to pose major animal health challenges. The lethal dose of $\mathrm{HCN}$ for cattle and sheep is 2.0 to $4.0 \mathrm{mg}$ perkg body weight.

The phytin levels were in the range of $0.97 \mathrm{mg} / \mathrm{g}$ DM to $1.55 \mathrm{mg} / \mathrm{g}$ DM as shown in Table 2. The levels are low and may not have adverse effects on ruminants. Phytates are known to increase requirements for minerals, especially phosphorus which forms insoluble complexes with phytic acid because of the special affinity for this metal ion and zinc (Tulean et al., 2008).
The tannin content of the forages used in the study were at tolerable levels and ranged from $0.98 \%$ in Andropogon tectorum to $2.27 \%$ in Alchornea cordifolia. In ruminants, condensed tannins have been shown to be beneficial. The protein-tannin complex in the rumen dissociates postruminally as a sort of by-pass protein and the effect of its presence may therefore be negligible. The saponin content of the forages ranged from 1.94\% in Andropogon tectorum to $3.76 \%$ in Gmelina arborea. Saponins are characterized by a bitter taste and foaming properties. In non-ruminants, retardation of growth rate due primarily to reduction in feed intake is probably the major cause.

Table 2: Phytochemical analysis of selected fodder crops used for the experiment

\begin{tabular}{llcccccc}
\hline \multirow{2}{*}{ Parameter } & \multicolumn{3}{l}{ Andropgontect Panicumma Aspilia } & \multicolumn{4}{c}{ Gmelinaa Alchorneac Bambusa } \\
& orum & ximum & Africana & rborea & ordifolia & Vulgaris & SEM \\
& $\mathrm{T}_{1}$ & $\mathrm{~T}_{2}$ & $\mathrm{~T}_{3}$ & $\mathrm{~T}_{4}$ & $\mathrm{~T}_{5}$ & $\mathrm{~T}_{6}$ & \\
\hline Tannins & 0.98 & 1.12 & 1.34 & 1.44 & 1.27 & 2.23 & 0.18 \\
Saponins & $1.94^{\mathrm{c}}$ & $2.18^{\mathrm{b}}$ & $3.33^{\mathrm{a}}$ & $3.76^{\mathrm{a}}$ & $1.95^{\mathrm{c}}$ & $2.71^{\mathrm{b}}$ & 0.31 \\
Oxalates & 0.98 & 1.01 & 0.74 & 1.45 & 0.17 & 1.23 & 0.18 \\
Hydrogen cyanide & 0.43 & 0.71 & 0.43 & 0.22 & 0.47 & 0.23 & 0.07 \\
Phytates & 1.05 & 1.32 & 1.25 & 1.55 & 1.11 & 0.97 & 0.09 \\
\hline a, b, c Means on the same row with different superscript are significantly $(\mathrm{p}<0.05)$ different. & & & &
\end{tabular}

However, in ruminants, saponins cause bloat but because saponins undergo bacterial degradation in the rumen, growth may not be retarded in ruminant animals (Kumar, 1991). Although the values of the anti-nutritional factors were not significant, their values however fell below the toxic levels recommended for ruminant animals (Kumar, 1991; Philip et al., 2014; Njidda, 2010). Mineral and vitamin composition of selected forage plants used for the study is as summarized in Table 3. The values obtained among the treatment means reveals that there were not significantly $(p>0.05)$ different. Values for minerals though not significant, fell within the normal range recommended for ruminants except magnesium $(\mathrm{Mg})$, sodium $(\mathrm{Na})$, iron $(\mathrm{Fe})$, copper $(\mathrm{Cu})$ and zinc $(\mathrm{Zn})$. Mineral deficiency could result in depression of animal performance. Sub clinical mineral deficiencies are widespread and responsible for yet unestimated, but probably great economic losses in livestock production.

However, mineral status of grazing animals in most African countries has received very little attention. The values recorded for vitamins indicate that there were also no significant ( $p>0.05)$ differences among the treatments but were in line with earlier reports (Akinsoyinu, 1986). 
Table 3: Mineral and vitamin compositions of selected fodder crops used in the experiment

\begin{tabular}{|c|c|c|c|c|c|c|c|}
\hline Minerals & $\begin{array}{l}\text { Andropogon } \\
\text { tectorum } \\
\mathrm{T}_{1}\end{array}$ & $\begin{array}{l}\text { Panicum } \\
\text { maximum } \\
\mathrm{T}_{2}\end{array}$ & $\begin{array}{l}\text { Aspilia } \\
\text { Africana } \\
\mathbf{T}_{3}\end{array}$ & $\begin{array}{c}\text { Gmelina } \\
\text { arborea } \\
\qquad \mathrm{T}_{4}\end{array}$ & $\begin{array}{c}\text { Alchornea } \\
\text { cordifolia } \\
\mathbf{T}_{5}\end{array}$ & $\begin{array}{c}\text { Bambusa } \\
\text { vulgaris } \\
\mathbf{T}_{6}\end{array}$ & SEM \\
\hline $\mathrm{Fe}(\mathrm{ppm})$ & 1.95 & 2.44 & 1.55 & 1.22 & 2.56 & 1.97 & 0.10 \\
\hline $\mathrm{Zn}(\mathrm{ppm})$ & 0.48 & 2.75 & 2.17 & 0.54 & 0.75 & 1.42 & 0.12 \\
\hline Co (ppm) & 1.09 & 1.11 & 0.49 & 0.42 & 0.34 & 0.29 & 0.05 \\
\hline $\mathrm{Cu}(\mathrm{ppm})$ & 0.81 & 1.07 & 0.65 & 0.17 & 0.81 & 0.25 & 0.11 \\
\hline $\mathrm{Cr}(\mathrm{ppm})$ & 0.35 & 3.14 & 2.34 & 0.12 & 1.29 & 0.91 & 0.08 \\
\hline $\mathrm{Na}(\mathrm{mg} / \mathrm{kg})$ & 0.93 & 0.49 & 0.84 & 1.21 & 1.19 & 0.97 & 0.11 \\
\hline $\mathrm{Mg}(\mathrm{mg} / \mathrm{kg})$ & 0.57 & 1.29 & 0.84 & 0.61 & 1.15 & 0.75 & 0.05 \\
\hline $\mathrm{K}(\mathrm{mg} / \mathrm{kg})$ & 0.35 & 0.92 & 0.75 & 0.22 & 0.65 & 0.35 & 0.04 \\
\hline $\mathrm{Ca}(\mathrm{mg} / \mathrm{kg})$ & 0.46 & 0.74 & 0.75 & 0.54 & 1.32 & 0.45 & 0.03 \\
\hline \multicolumn{8}{|l|}{ Vitamins } \\
\hline Vitamin C (mg/100g) & 1.53 & 2.22 & 1.03 & 1.62 & 0.55 & 0.85 & 0.09 \\
\hline Vitamin $\mathrm{A}(\mu \mathrm{g} / 100 \mathrm{~g})$ & 1.17 & 0.62 & 1.23 & 0.65 & 0.79 & 0.87 & 0.17 \\
\hline Vitamin E $(\mu \mathrm{g} / 100 \mathrm{~g})$ & 0.41 & 0.09 & 0.32 & 0.57 & 0.53 & 0.44 & 0.87 \\
\hline Vitamin B1 (mg/100g) & 0.71 & 0.44 & 1.43 & 0.55 & 1.03 & 0.99 & 0.04 \\
\hline Vitamin B6 (mg/100g) & 1.05 & 0.76 & 0.75 & 0.92 & 1.16 & 0.89 & 0.06 \\
\hline Vitamin B12 $(\mu \mathrm{g} / 100 \mathrm{~g})$ & 1.45 & 0.24 & 0.90 & 2.11 & 1.76 & 0.43 & 0.04 \\
\hline
\end{tabular}

\section{Conclusion}

The study indicated that among the forages used for this study, Andropogon tectorum had low mineral content but could be combined with other forages for use by grazing animals for optimum production.

\section{References}

Akinsoyinu, A. O. 1986. Minimum phosphorus requirement of dwarf goats for maintenance. Trop. Agri. (Trinidad), 63:333-335.

Akinsoyinu, A. O. and Onwuka, C. F. I. 1988. Mineral constituents of some browse plants used in ruminant feeding in southern Nigeria. Nigerian J. Ani. Prod. 15: 57-62.

Amata. I. A. and Lebari, T. 2011. Comparative evaluation of the nutrient profile of four selected browse plants in the tropics, recommended for use as nonconventional feeding materials. African Journal of Biotechnology, 10(64); 14230-14233.
AOAC 2002. Official methods of analysis of the official analytical chemists, $17^{\text {th }}$ ed. (Horwitz, W.ed) Association of official analytical chemists, Washington DC.

Babayemi, O. J., Demeyer, D. and Fievez, V. 2004. In vitro fermentation of tropical browse seeds in relation of their content of secondary metabolites. J. Ani. Feed Sci. 13 Suppl. 1:31-34

Barry, H. J. 1987. Secondary compounds of forages. In: Nutrition of herbivores. Hacker, J. B. and Ternouth, J. H. (eds) A. P. Sydney pp. 91-120.

Barry, T. N. and Duncan, S. J. 1984. The role of condenced tannins in the nutritional value of Lotus pedunculatus for sheep. I. Voluntary intake. Journal of Association of Official Analytical Chemists 65:496497.

Belmar, R., Nava-Montero, R., Sandoval-Castro, C. and Menab, 


\section{Mineral and proximate composition of selected forages}

J . M . 1999 . J a c k b e a n (canuvaliaensiforms L. DC) in poultry diets: Anti-nutritional factors and detoxification studies. A. Review. Poultry Sci.J. 55(1) 37-59

Cheeke, P. R. and L. R. Shull 1985. Tannins and Polyphenolic compounds. In: Natural Toxicants in Feeds and Poisonous Plants. AVI Publishing Company, USA.

D'Mello, J. P. F. 2000. Anti-nutritional factors and mycotoxins. In: Farm animal metabolism and Soybeans CAB International Wallingford, UK, pp: 383-403.

Duncan, D. B. 1955. New Multiple Range and Multiple F Test Biometrics. 11:1 -42 .

Habtamu, F. and Negussie, R. 2014. Antinutritional factors in plant foods: Potential health benefits and adverse effects. International Journal of Nutrition and Food Sciences, 2014; 3(4): 284-289. Published online July 20 , 20014 (http://www.sciencepublishinggroup com / j/ i jnfs $)$ d o i : 10.11648/j.ijnfs.20140304.18. ISSN: 2327-2694 (Print); ISSN: 2327-2716 (Online).

Judson, G. J. and McFarlane, J. D. 1998. Mineral disorders in grazing livestock and the usefulness of soil and plant analysis in the assessment of these disorders. Aust. J. Experi. Agric., 38: 707-723.

Junsomboon, J. and Jakmunce, J. 2011. Determination of potassium, sodium and total alkalies in portland cement admixtures and water of concrete by a simple flow injection flame photometric system by J un somboon Jaroon and JakmunceJaroon. J. Autom. Methods Manage. Chem.,fl
Kamar, A. 1991. Survey on the abdomen and organs of the digestive system. Veterinary Surgical Techniques. Vicas Publishing House PVT Limited, pp. $264-315$.

Kubmarawa, D., Andenyang, I. F. H. and Magomya, A. M. 2008. Amino acid profile of two non-conventional leafy vegetables, Sesamumindicum and Balanitesaegyptiaca. African Journal of Biotechnology. 7 (19): 3502-3504.

Kumar, R. 2003. Anti-nutritive factors, the potential risk of toxicity and methods $\mathrm{t}$ o a $11 \mathrm{e} \mathrm{vi}$ a $\mathrm{e} \mathrm{th}$ e $\mathrm{m}$. http://www.faop.org/DOCREP/003/ TO632E/TO632E10.htm

Le Houerou, H. N. 1980. Chemical composition and nutritive value of browse in tropical W. Africa. In: H. N. Le Houerou (ed), Browse in Africa: current state of knowledge. ILCA Addis Ababa Ethiopia pp. 261-289.

Maga, J. A. 1982. Phytate, its chemistry, occurrence, food interaction, nutritional significance and methods of analysis, J. Agric. Food and Chem., pp $1-5$.

Njidda, A. A., Ikhimioya, I., Muhammad, B. F. and Amaza, I. B. 2010. Chemical Composition, fibre fraction and Anti-Nutritive Substances. In: O. J. Babayemi, O. A. Abu, and E. O. Ewuola (eds.). Proc. $35^{\text {th }}$. Nig. Soc. For anim. Prod. 14-17 March, 2010, University of Ibadan, Nigeria. pp 477-480.

Norton, B. W. 2003. The Nutritive value of $\mathrm{t} r \mathrm{e}$ l e $\mathrm{g} \mathrm{u} \mathrm{m} \mathrm{e} \mathrm{s.}$ http://www.fao.org/ag/AGPC $/ \mathrm{doc} / \mathrm{Publicat} / \mathrm{Gutt}$ shel/x5556e0j.htm.pp.1-10

Odoemelam, V. U. and Ahamefule, F. O. 2006. Effect of de-hulling on proximate compositions, antinutritional properties and mineral 
content of Canavaliaplagiosperma. Trop. J.Anim. Prod, 31(2) 167-175.

Oke, D. B., Adeyemi, O. A., Oke, M. O. and Akinpelin, M. I. 2007. Utilization of citrus waste in broiler diets. NSAP. Proc. $32^{\text {nd }}$ Ann. Conf. of NSAP. Calabar, pp. 316-318.

Polshettiwar, S. A., Ganjiwale, R. O., Wadher, S. J. and Yeole, P. G. 2007. Spectro photo metric estimation of total tannins in some ayurvedic eye drops. Indian J. Pharmaceutical Sci., 69(4): 574-576.

Rittner, U. and Reed, J. D. 1992. Phenolics and In vitro degradability of protein fibre in West African browse. J. Sci. Food and Agriculture 58, 21-28.

SLUS-AK 1989. Soils and Land Use Studies.Government Print Office, Uyo, AkwalbomState.Soil Survey Staff, 1994.Keys to Soil Taxonomy. Soil Management Service (SMSS). Tech. Monogr. No. 19.30-60.

Smitha Patel, P. A., Alagundagi, S. C. and Salakinkop, S. R. 2013. The antinutritional factors in forages - A Review. Current biotica 6(4): 516526, 2013, ISSN 0973-4031.

Soetan, K. O. 2008. Pharmacological and other beneficial effects of antinutritional factors in plants - A Review. Afr. J. Biotechnol. 7(25): pp 4713-4721.
Teferedegne, B. 2000. New perspectives on the use of tropical plants to improve ruminant nutrition. Pro. Nutr. Soc., 59:209-214.

Tuleun, C. D., Carew, S. N. and Ajiji, S. N. 2008. The feed value of velvet beans (Mucunautilis) for laying chickens. In: Proc. $33^{\text {rd }}$ Ann. Conf. of the Nig. NSAP. OlabisiOnabanjo University, Ayetoro, Ogun States, pp. 405-408.

Underwood, E. J. and Scuttle, N. F. 1999. The mineral nutrition of livestock ( $3^{\text {rd }}$ ed). CAB International, Wellington and New York, USA.

Vegas, E. and McDowell, L. R. 1997. In mineral differences of cattle in Central America and the Caribbean, emphasizing Costa Rica. Proceedings of the International conference of livestock in the Tropics, University of Florida, Gainesville, Florida. May, Gainesville, Florida, 1997, 99-144.

Waghorn, G. 2008. Beneficial and detrimental effects of dietary condensed tannins for sustainable sheep and goat production - Progress and challenges. Animal Feed Science and Technology 147 (2008) pp 116139.

Received: $25^{\text {th }}$ July, 2018 Accepted: $21^{\text {st }}$ December, 2018 